\title{
Prokaryotic Expression, Purification and Activity Detection of Phosphodiesterase 2A Protein
}

\author{
Lei Jiang \\ Laboratory of Biochemical Engineering, College of Pharmaceutical Engineering and Life \\ Sciences, Changzhou University, Changzhou 213000, China \\ E-mail: lei_jiang2020@sina.com
}

\begin{abstract}
Shenghu Yan (Corresponding author)
Laboratory of continuous flow technology in the petroleum and chemical industry engineering, College of Pharmaceutical Engineering and Life Sciences, Changzhou University, Changzhou 213000, China
\end{abstract}

Tel: +86-0519-86330177 E-mail: ysh@cczu.edu.cn

Received: March 11, 2020 Accepted: April 1, 2020

doi:10.5296/jbls.v11i2.16650 URL: https://doi.org/10.5296/jbls.v11i2.16650

\begin{abstract}
Depression is associated with changes in cyclic guanosine monophosphate (cGMP) levels. Depression can be improved by increasing the cGMP concentration through the cGMP/PKG pathway with PDE2A inhibitors. This study is aimed to improve the expression of a highly active PDE2A protein with an Escherichia coli vector ST6 for the screening of PDE2A inhibitors. PDE2A gene was obtained through polymerase chain reaction. A recombinant plasmid of ST6-PDE2A was built by seamless cloning and then introduced into E. coli BL21 (DE3). The cultivation conditions were optimized to increase target protein expression. The expressed protein was purified with Ni-NTA affinity chromatography. Its purified activity was measured by a PDE-GloTM phosphodiesterase kit. An maximized protein expression was obtained by cultivating E. coli BL21 with ST6-PDE2A in the YT medium at $37{ }^{\circ} \mathrm{C}$ till $\mathrm{OD}_{600}$ reached to 0.6-0.8 and then by inducible expressing with $1 \mathrm{mM}$ IPTG at $16{ }^{\circ} \mathrm{C}$ for 40 hours. The resultant active protein has an $\mathrm{EC}_{50}$ of $0.1196 \mathrm{mg} / \mathrm{ml}$.
\end{abstract}

Keywords: depression, phosphodiesterase 2A, prokaryotic expression, purification 


\section{Introduction}

Depression is a common mood and emotional disorder. Statistics from Worth Health Organization suggest that globally, the rate of depression is $11 \%$ and there are up to 1 million suicides associated with depression every year (Mann JJ, 2003; Song Y et a1., 2008). This disease is manifested as persistent and significant low mood, loss of interest, and low self-esteem. It is ubiquitously accompanied by cognitive impairments in perception, memory, learning, and execution to various degrees.

Phosphodiesterases (PDEs), which mainly act on cyclic adenosine monophosphate (cAMP) and cyclic guanosine monophosphate (cGMP), have recently attracted attention from the field of depression therapy. Both cAMP and cGMP can regulate the corresponding downstream protein kinases. Their's activating transcription factors can control the expression of specific genes inducing or relieve the depressive symptoms (Mathew S J et al., 2008; Alt Andrew; 2006; Hebb ALO \& Robertson HA, 2007). The PDE4 inhibitors showed a great anti-depression effect in a rodent behavior tests (O'Donnell J \& Zhang H., 2004; Zhang HT et al., 2002; Zeller E et al., 1984). Among them, Rolipram entered phase II clinical trial (Burgin AB et al., 2010), but it was not listed due to side effects such as nausea and vomiting caused by a lack of PDE4 subtype specificity (Zhang HT et al., 2002). PDE2 inhibitors are protective against many different forms depression-like behaviors(Zhang Chong et al., 2017). PDE2 has high expression in the brain regions known to be related to depression (Lakics V et al., 2010). But its inhibitor Bay 60-7550 has low brain penetrability, and other inhibitors also have their own disadvantages. Hence, more efficient PDE inhibitors need to be developed.

Development of the PDE inhibitors requires active and stable PDEs. In this research, the PDE2A gene was amplified through polymerase chain reaction (PCR) and used to build a recombinant plasmid ST6-PDE2A. The PDE2A recombinant protein was expressed in Escherichia coli BL21 (DE3) and then purified with Ni-NTA affinity chromatography. The activity of PDE2A was examined through a PDE-GloTM ${ }^{\text {TM }}$ PDE kit (Promega).

\section{Materials and Methods}

\subsection{Apparatuses and Equipment}

The equipment used here included an enzyme-labeled instrument (Tecan), a gel-imaging system (Bio-Rad), an ultrasonic cell disruptor (Sonics), and a chromatography (Smart-Lifesciences, Changzhou, China).

\subsection{Culture Media and Reagents}

Lauria-Bertani (LB) liquid medium $(100 \mathrm{ml})$ consisted of tryptone $(1 \mathrm{~g}), \mathrm{NaCl}(1 \mathrm{~g})$ and yeast extract $(0.5 \mathrm{~g})$ dissolved in $100 \mathrm{ml}$ of distilled water. Yeast-tryptone $(\mathrm{YT})$ medium $(100 \mathrm{ml})$ consisted of tryptone $(1.6 \mathrm{~g})$ and yeast extract $(1 \mathrm{~g})$ dissolved in $100 \mathrm{ml}$ of distilled water. Terrific broth (TB) $(100 \mathrm{ml})$ consisted of tryptone $(1.2 \mathrm{~g})$, yeast extract $(2.4 \mathrm{~g}), 2.5 \mathrm{ml}$ of glucose liquid $(0.2 \mathrm{~g} / \mathrm{ml})$ and $10 \mathrm{ml}$ of phosphate buffer dissolved in $90 \mathrm{ml}$ of distilled water. 
Phosphate buffer (PBS, pH7.2) consisted of $\mathrm{KH}_{2} \mathrm{PO}_{4}(0.24 \mathrm{~g}), \mathrm{Na}_{2} \mathrm{HPO}_{4}(1.44 \mathrm{~g}), \mathrm{NaCl}(0.2 \mathrm{~g})$ and $\mathrm{KCl}(8 \mathrm{~g})$ dissolved in $1000 \mathrm{~mL}$ of distilled water. The buffers used in Ni-NTA affinity chromatography included Buffer A (20 mM Tris, $0.5 \mathrm{M} \mathrm{NaCl}, \mathrm{pH}$ 8.0), Buffer B (20 mM Tris, $0.5 \mathrm{M} \mathrm{NaCl}, 10 \mathrm{mM}$ imidazole, $\mathrm{pH}$ 8.0), Buffer C (20 mM Tris, $0.5 \mathrm{M} \mathrm{NaCl}, 30 \mathrm{mM}$ imidazole, $\mathrm{pH}$ 8.0), and Buffer D (20 mM Tris, 0.5 M NaCl, $250 \mathrm{mM}$ imidazole, $\mathrm{pH}$ 8.0). The composition of dialysate is $20 \mathrm{mM}$ Tris and $150 \mathrm{mM} \mathrm{NaCl}, \mathrm{pH}$ 8.0.

The PDE-Glo ${ }^{\mathrm{TM}}$ Phosphodiesterase kit was purchased from Promega.

\subsection{Strains and Vectors}

The strains including E. coli DH5 $\alpha$ and BL21(DE3) were stored in our laboratory. The vector plasmid ST6 was provided by Beijing Baixinyi Co. Ltd. (China).

\subsection{Primers Design}

Using the human PDE2A gene sequence as the template and plasmid ST6 as the vector, seamless cloning primers ( $\mathrm{P}_{1}$ : forward primer, $\mathrm{P}_{2}$ : reverse primer) were designed. The restriction endonuclease Sfi I (GGCCNNNN^NGGCC) was introduced into the primers. 5' end of primers was the vector sequence and 3 ' end of primers was the PDE2A gene sequence.

The primers were:

\section{P1:5' - GCTGCCCAGCCGGCGATGGCCCAAGCGGCCGATGAGTATACCAAAC-3' P2:5' - GTCCTTGTAGTCATGGCCGACGGGGCCCTCCTCATCCAGGAAG-3'}

\subsection{Amplification of the Target Gene}

PCR amplification was conducted with the cDNA of PDE2A as the template. The PCR system $(50 \mu \mathrm{l})$ consisted of $10 \times \mathrm{PCR}$ buffer $(5 \mu \mathrm{l}), 25 \mathrm{mM} \mathrm{MgSO} 4(3 \mu \mathrm{l})$, ddH2O (32 $\mu \mathrm{l})$, KOD-Plus-Neo $(1.5 \mu \mathrm{l})$, cDNA $(1.5 \mu \mathrm{l}), 2 \mathrm{mM}$ dNTPs $(5 \mu \mathrm{l})$, and $10 \mu \mathrm{M}$ forward and reverse primers (each $1 \mu \mathrm{l}$ ). The reaction conditions consisted of an initial denaturizing of 2 minutes at $95^{\circ} \mathrm{C}$ and 30 cycles of 30 seconds at $94^{\circ} \mathrm{C}, 30$ seconds at $60^{\circ} \mathrm{C}$ and 1 minute at $72{ }^{\circ} \mathrm{C}$, followed by extension at $72{ }^{\circ} \mathrm{C}$ for 10 minutes and cooling to $4{ }^{\circ} \mathrm{C}$. The PCR products were tested by $1 \%$ agarose gel electrophoresis and recycled by an AidQuick PAGE extraction kit.

\subsection{Construction and Conversion of the Recombinant Expression Vector}

The recycled target gene was seamlessly cloned with the ST6 vector digested by Sfi I in the reaction system $(10 \mu \mathrm{l})$, which consisted of the buffer solution $(5 \mu \mathrm{l})$, ST6 plasmid after Sfi I digestion $(2.5 \mu \mathrm{l})$ and the recycled target gene fragments $(2.5 \mu \mathrm{l})$. The system reacted at $50{ }^{\circ} \mathrm{C}$ for 35 minutes to form the recombinant expression vector ST6-PDE2A. The seamlessly cloned product was introduced into the $E$. coli $\mathrm{DH} 5 \alpha$ competent cells and then cultured on the LB solid medium with $100 \mu \mathrm{g} / \mathrm{ml} \mathrm{Amp} \mathrm{at} 37^{\circ} \mathrm{C}$ for 24 hours. After the positive clones were tested by Sfi I digestion and sequencing, the ST6-PDE2A was extracted and further introduced into the $E$. coli BL21 (DE3) competent cells. After cultivation under the same conditions as above, the transformants were used to express the target protein. 


\subsection{Induced Expression of the Target Protein}

The basic culture conditions were as follows: the transformants were inoculated into LB liquid medium ( $3 \mathrm{~mL}$ ) with $100 \mu \mathrm{g} / \mathrm{ml} \mathrm{Amp} \mathrm{and} \mathrm{cultured} \mathrm{overnight} \mathrm{at} 37^{\circ} \mathrm{C}$. After that, $1 \mathrm{ml}$ of the culture was transferred into $100 \mathrm{ml}$ of different media with $100 \mu \mathrm{g} / \mathrm{ml} \mathrm{Amp}$, followed by shaking culture at $37{ }^{\circ} \mathrm{C}$ till the OD600 reached to 0.6-0.8. Afterward, the temperature was adjusted and IPTG was added into the media for induced expression.

The culture conditions investigated here included medium type (LB, YT, and TB), IPTG concentration $(0.1,0.5$ and $1 \mathrm{mM})$, expression temperature $\left(13{ }^{\circ} \mathrm{C}, 16^{\circ} \mathrm{C}\right.$ and $\left.19{ }^{\circ} \mathrm{C}\right)$, and expression time (20, 30 and 40 hours).

\subsection{Detection and Purification of the Target Protein}

The protein expression fluid was centrifuged at $4{ }^{\circ} \mathrm{C}$ and $8000 \mathrm{rpm}$ for 10 minutes. Obtained precipitates were washed twice with PBS (pH 7.2) and resuspended in $10 \mathrm{ml}$ of Buffer A, and then ultrasonically disrupted at $0{ }^{\circ} \mathrm{C}$. A part of each disrupted sample was centrifuged at $4{ }^{\circ} \mathrm{C}$ and $12000 \mathrm{rpm}$ for 30 minutes, and the precipitate was resuspended in Buffer A with the same volume as the disrupted sample before centrifugation. $10 \mu \mathrm{l}$ of disruption sample (whole proteins), the supernatant of disruption sample (soluble proteins), and the precipitate resuspension (insoluble proteins) were separately taken for SDS-PAGE and photographed by the gel-imaging system.

The soluble proteins in the supernatant were purified by Ni-NTA affinity chromatography. Firstly, the Ni column was balanced with Buffer A and the supernatant was filtered through $0.45-\mu \mathrm{m}$ filter membranes. Each sample was then added into the column at a flow rate of 2.0-3.0 $\mathrm{ml} / \mathrm{min}$. The protein impurities were eluted with Buffer B and Buffer C, and the target protein was eluted with Buffer $\mathrm{D}$. The eluent of the target protein was dialyzed at $4{ }^{\circ} \mathrm{C}$ for 30 hours and the dialyzed was exchanged every 10 hours. The volume ratio of protein eluent and dialyzate was 1:50. The purified target protein eluent was concentrated 10 times prior to SDS-PAGE.

\subsection{Measurement of Target Protein Concentration}

\subsubsection{Protein Standard Curve}

$50 \mu \mathrm{l}$ of BSA solution $(0,0.02,0.04,0.06,0.08,0.1 \mathrm{mg} / \mathrm{ml})$ and $200 \mu 1$ of Coomassie brilliant blue R250 solution were mixed in a 96-well plate. The absorbance at $595 \mathrm{~nm}$ was measured after standing for 10 minutes. The correlation between absorbance and BSA concentration was $y=0.2491 x-0.1015\left(R^{2}=0.9963\right.$, Fig. 1), which indicated that the data is valid. 


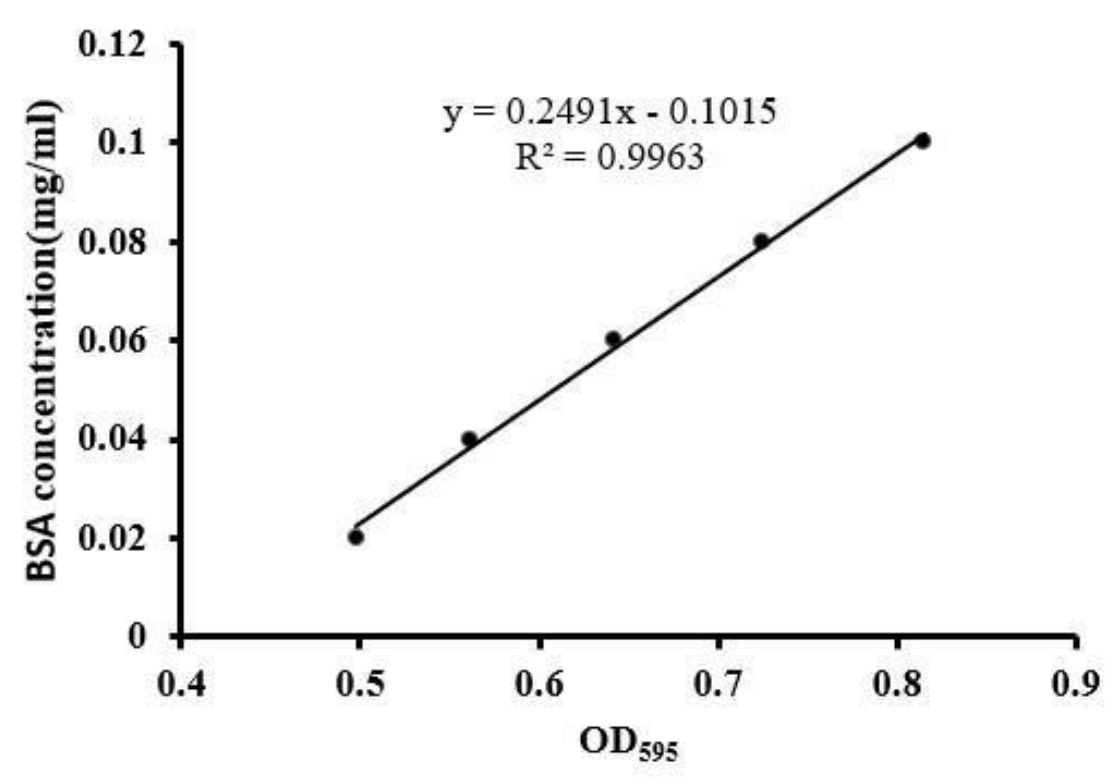

Figure 1. Standard curve of BSA

\subsubsection{Protein Concentration Measurement}

The absorbance of the target protion solution at $595 \mathrm{~nm}$ was measured by the same method of BSA solution. The data were controlled within 0.2-0.8. Then the target protein concentration was obtained according to the standard curve.

\subsection{Measurement of Target Protein Activity}

The activity of the target protein was measured with the PDE-Glo ${ }^{\mathrm{TM}}$ Phosphodiesterase kit. The purified target protein solution was diluted 2, 4, 8, 16, 32, 64, and 128 times, forming a series of diluted protein solutions. Then on a 384 -well plate, $5 \mu 1$ of $1 \times$ PDE-Glo ${ }^{\text {TM }}$ reaction buffer was added to well $1 ; 2.5 \mu$ of $1 \times \mathrm{PDE}_{-G_{1}}{ }^{\mathrm{TM}}$ reaction buffer and $2.5 \mu 110 \mu \mathrm{M}$ cGMP were added to well $2 ; 2.5 \mu 1$ of $10 \mu \mathrm{M}$ cGMP and $2.5 \mu 1$ of diluted protein solutions were added to well 3-10 respectively. After reaction for 20 minutes, $2.5 \mu \mathrm{l}$ of PDE-Glo ${ }^{\mathrm{TM}}$ termination buffer was added to all wells. In 5 minutes, $2.5 \mu \mathrm{l}$ of PDE-Glo ${ }^{\mathrm{TM}}$ detection buffer was added to all wells. After reaction for another 30 minutes, $10 \mu \mathrm{l}$ of Kinase-Glo® reagent was added to all wells. The relative light unit (RLU) was detected after10 minutes of reaction at room temperature, and the cGMP hydrolysis rate was calculated as follows:

$$
\text { Hydrolysis rate }_{\mathrm{cGMP}}=\frac{R L U_{\text {enzyme \& substrate }}-R L U_{\text {substrate }}}{R L U_{\text {blank }}-R L U_{\text {substrate }}}
$$

EC50 was determined by the GraphPad Prism: a scatter diagram was plotted with protein concentration (logarithmic scale, base 10) as the $\mathrm{x}$-axis and cGMP hydrolysis rate as the $y$-axis, and non-linear regression (curve fit) was done with the template of $\log$ (agonist) vs. response-Variable slope. Then $\mathrm{EC}_{50}$ can be determined statistically. 


\section{Macrothink}

\section{Results}

\subsection{Amplification of Target Gene Fragments}

The PED2A template used in the primer design was 1020 bp long. The PCR amplification results (Fig. 2) showed that the fragment size consistent with the design. Then the gene sequence was further validated by sequencing, and the isoelectric point of target protein was presumed to be 4.77 according to its amino acid sequence. The target gene fragments recycled by gel extraction were seamlessly connected with the line ST6 vector digested by Sfi I to form a recombinant vector ST6-PDE2A.

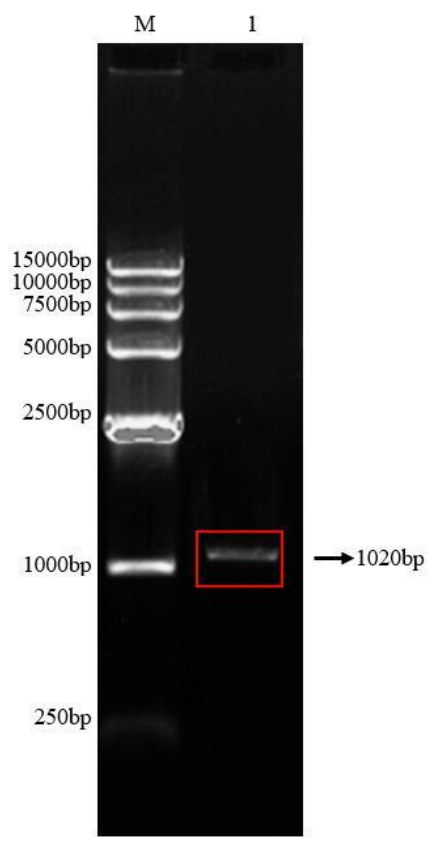

Figure 2. PCR amplification of the target gene fragment

M: DL 15000 DNA Marker; 1: PDE2A PCR product

\subsection{Solubility of the Target Protein}

The ST6-PDE2A was transferred into BL21 (DE3) for protein expression. Then whole proteins precipitate proteins, and supernatant proteins were gathered for SDS-PAGE (Fig. 3). As expected, all three samples showed evident target protein band at $37 \mathrm{KD}$. The protein band in supernatant was less evident than that of the precipitates, suggesting most of target protein existed as inclusions. 


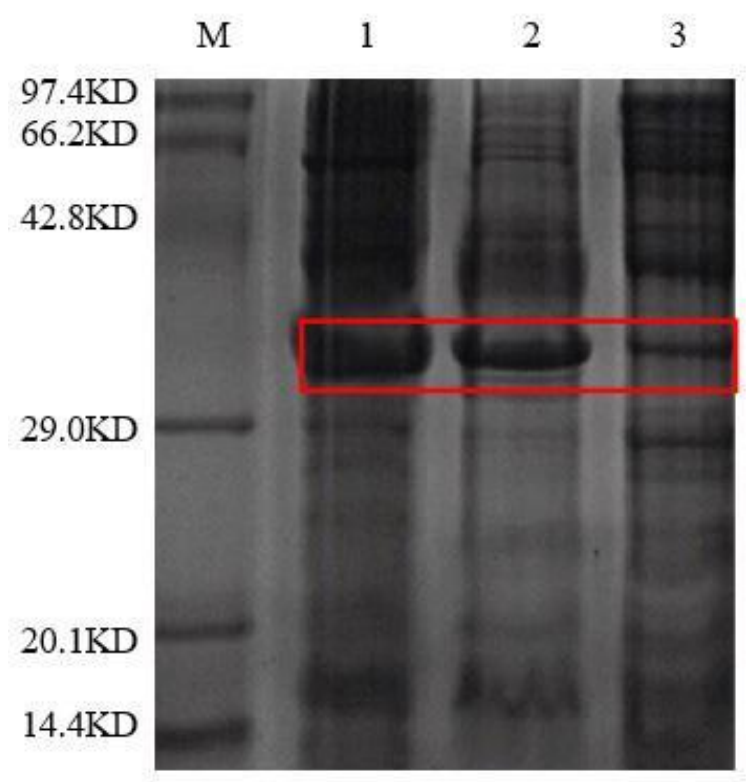

Figure 3. SDS-PAGE analysis of solubility of expressed PDE2A

M: protein Marker; 1: whole proteins induced for 40 hours; 2: precipitate proteins after ultrasonic disruption; 3: supernatant proteins after ultrasonic disruption.

\subsection{Purification of the Target Protein}

The soluble proteins in the supernatants were purified by affinity chromatography. The flow-through liquid, eluents of Buffer B, Buffer C, and Buffer D were collected separately for SDS-PAGE with unpurified supernate. The results (Fig. 4) showed that the content of the target protein increased significantly in eluent of Buffer D.

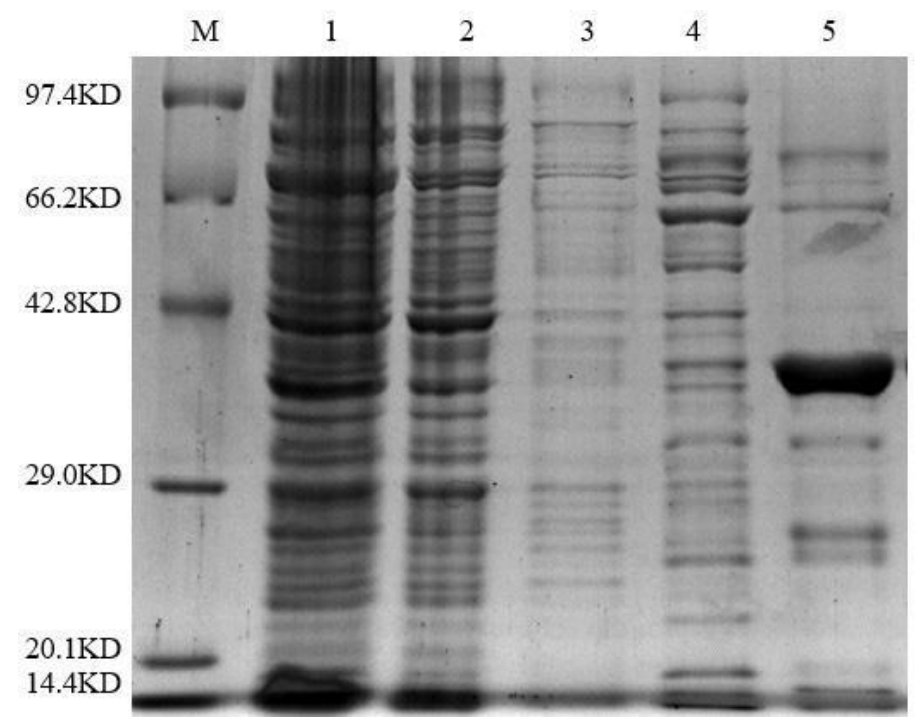

Figure 4. SDS-PAGE analysis of purified PDE2A

M: protein Marker; 1: supernate after ultrasonic disruption; 2: flow-through liquid; 3: eluent of Buffer B; 4: eluent of Buffer C; 5: eluent of Buffer D (concentrated 10 times) 


\section{Macrothink}

\subsection{Condition Optimization of Target Protein Expression}

The concentration of the target protein was low in the supernatant (Fig. 3). To enhance the expression level of soluble proteins, type of culture medium, induced expression temperature and time, and concentration of inducer (IPTG) were optimized. The protein expression level maximized when the recombinant bacteria were cultured at $16^{\circ} \mathrm{C}$ for 40 hours in YT medium with $1 \mathrm{mM}$ IPTG. High temperature, high concentration inducer and nutrient rich medium can promote protein expression. However, too fast protein expression will lead to misfolding and inclusion formation. Therefore, in order to improve the expression of soluble protein, it is necessary to control the culture conditions. In this research, YT medium is better than LB and TB. One mM IPTG is better than $0.5 \mathrm{mM}$ and $0.1 \mathrm{mM}$ IPTG. But in terms of temperature, the soluble protein expression level was the highest at $16^{\circ} \mathrm{C}$. When the temperature is too low, the whole protein expression is affected by the low protein expression speed. If the temperature is too high, the soluble protein expression is affected because the protein could not fold correctly in time. (Fig. 5).

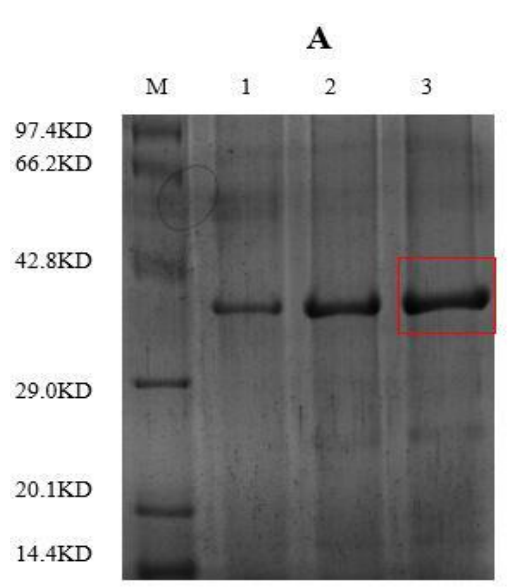

C

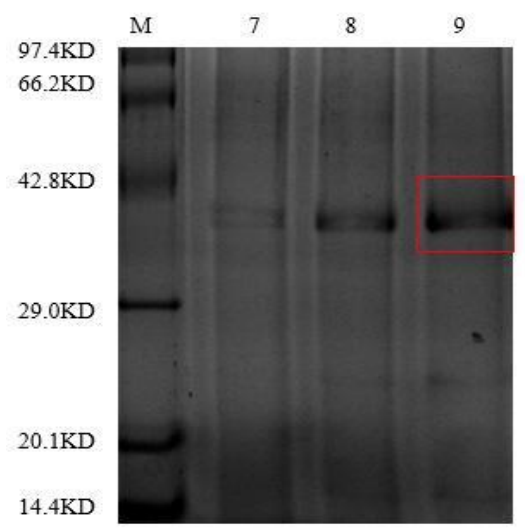

B

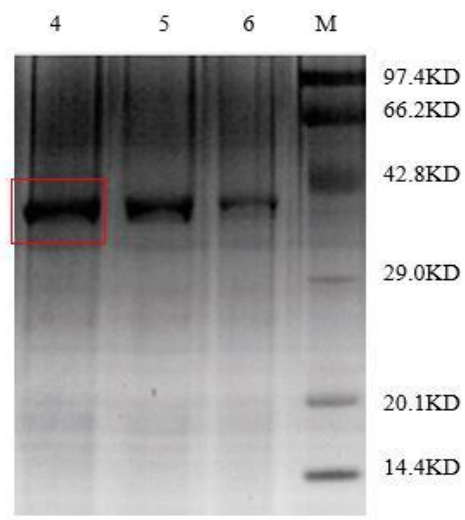

D

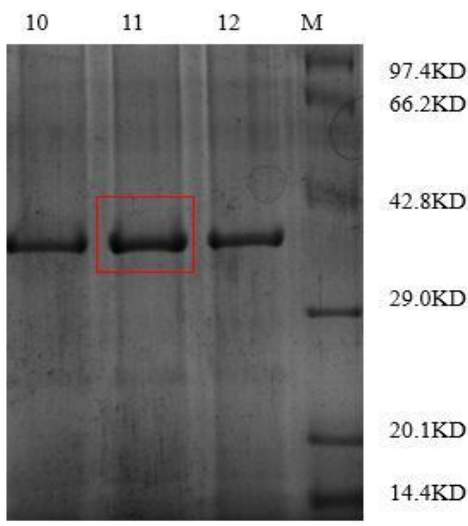

Figure 5. SDS-PAGE analysis of PDE2A expression under different conditions

(A) 1-3: expression time of 20, 30 and 40 hours; (B) 4-6: culture media of YT, TB and LB; (C) 7-9: final IPTG concentration of 0.1, 0.5 and $1 \mathrm{mM}$; (D)10-12: expression temperature at 13,16 and $19{ }^{\circ} \mathrm{C}$. 


\section{Macrothink}

\subsection{Protein Concentration and Activity Measurements}

Based on the BSA standard curve, the concentration of the target protein was $0.5389 \mathrm{mg} / \mathrm{ml}$. With the increase of PDE2A concentration, the hydrolysis rate of the substrate cGMP increased. Through GraphPad curve fitting, the EC50 of PDE2A was $0.1196 \mathrm{mg} / \mathrm{ml}$ (Fig. 6).

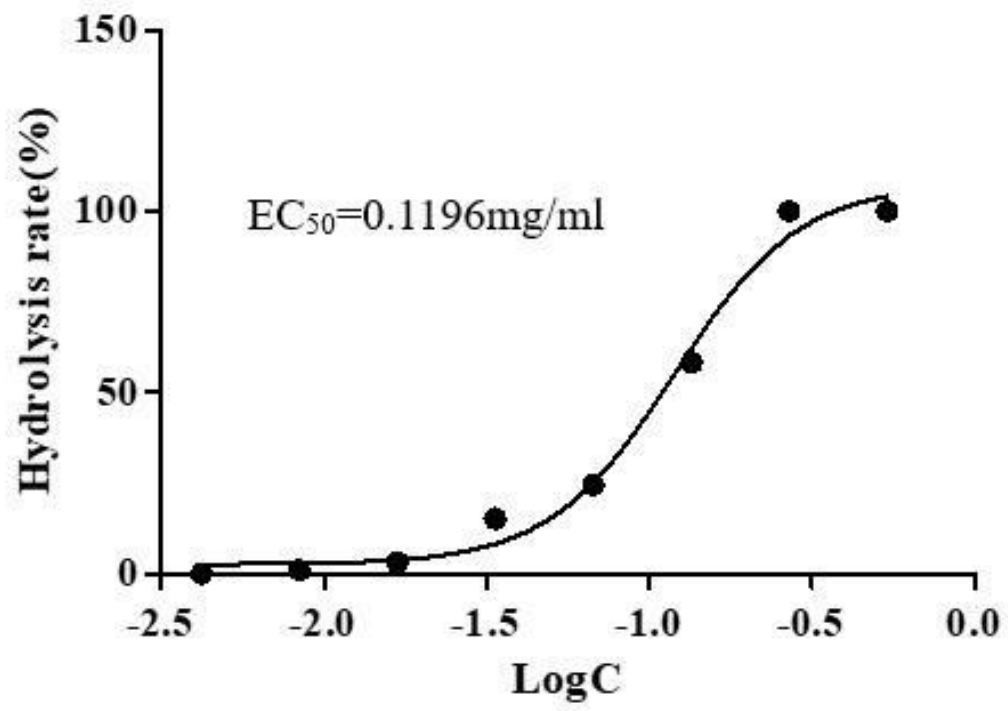

Figure 6. Activity assay of PDE2A

\section{Discussion}

PDE2A, belonging to the dual-structured PDE family, can simultaneously hydrolyze cGMP and cAMP (Conti $\mathrm{M}$ et al., 2003) and can regulate the intracellular cGMP and cAMP levels so as to affect the physiological activities involving these two secondary messengers. Since cAMP and cGMP are both pivotal in central nervous system diseases, the structural distribution and biochemical properties of PDE2A imply PDE2A may be a new target of central nervous system diseases (Teng FY \& Tang BL, 2006; Houslay MD et al., 2005; Conti M \& Beavo J., 2007; Bender AT \& Beavo JA, 2006; Esposito K et al., 2009).

Though anti-depressants have been applied clinically since the 1980s, their therapeutic effects are limited (Kennedy SH., 2013). Moreover, most of the existing anti-depressants have significant side effects, and the anti-depressive mechanisms are not fully known. Hence, it is necessary to develop new anti-depressants with better effects and study their mechanisms. PDE inhibitors are potential anti-depressants. The research on PDE inhibitors needs abundant active PDE proteins, thus PDEs expression and purification are also major aspects of research in this field. Hutson et al. (2011) cloned the relevant PDE gene into the pcDNA3.3-TOPO vector, stably transfected HEK 293 or CHO cells to express relevant PDE proteins. However, this expression system is expensive and highly demanding for technicians. In this study, E. coli BL21 (DE3) strains were used as receptor bacteria to express proteins in vitro; this method is inexpensive, easy to operate, high protein expression and stable activity. Chen et al. (2020) constructed a pET28a-C. albicans PDE2 recombinant plasmid to express PDE2A protein in $E$. 
coli BL21 (DE3) and obtained $0.385 \mathrm{mg} / \mathrm{ml}$ proteins after Ni-NTA affinity chromatography, while in this study, $0.5389 \mathrm{mg} / \mathrm{ml}$ was obtained. Many methods are available for PDE protein activity detection and PDE inhibitor screening. Meng F et al. (2012), Shao Y X et al. (2014) and Claffey et al. (2012) used $\left[{ }^{3} \mathrm{H}\right] \mathrm{cGMP}$ and $\left[{ }^{3} \mathrm{H}\right] \mathrm{cAMP}$ scintillation proximity assays for high-flux drug screening, but the use of radioisotopes will cause environmental pollution and requires special processing of experimental materials, while the PDE-Glo ${ }^{\mathrm{TM}}$ phosphodiesterase kit used in our study is cost-effective and has little impact on environment.

In addition to the vector and kit are different from previous studies, this study also probed into the optimization of protein expression conditions. Expression in Escherichia coli can easily lead to the formation of inclusions. When the protein is expressed too fast, it cannot fold properly and form inclusion body. Hence, selection of induction temperature, inducer concentration, induction time and medium type is very important. Jian Z et al. (2013) constructed a pPDE258 (N-Trx) expression vector, transferred it into BL21-CodonPlus (DE3) to express PDE2A and found the optimal expression conditions as: cultured in the LB media at $37^{\circ} \mathrm{C}$ till $\mathrm{OD}_{600}$ reached to 0.4 , cool to $16^{\circ} \mathrm{C}$, and induced with $0.5 \mathrm{mM}$ IPTG for 16 hours after OD600 reaching 0.8. In this study, a recombinant expression plasmid ST6-PDE2A was established and expressed in BL21 (DE3). The optimize protein expression conditions were: cultured in YT media at $37^{\circ} \mathrm{C}$ till OD 600 reach to $0.6-0.8$, cool to $16^{\circ} \mathrm{C}$, and induced with $1 \mathrm{mM}$ IPTG for 40 hours. The above findings imply that optimal culture conditions are slightly different when different plasmids are adopted.

In conclusion, an ST6-PDE2A expression vector was successfully established in this research. Then the protein expression conditions were optimized, and the PDE2A with certain purity and activity was acquired through Ni-NTA affinity chromatography, which underlies the development and functional investigation on PDE2A inhibitors.

\section{Conflict of interest}

The authors declare no conflict of interest.

\section{References}

Alt, A., Nisenbaum E. S., Bleakman, D., et al. (2006). A role for AMPA receptors in mood disorders. Biochem Pharmacol, 71, 1273-1288. https://doi.org/10.1016/j.bcp.2005.12.022

Bender, A. T., Beavo, J. A. (2006). Cyclic nucleotide phosphod-iesterases: molecular regulation to clinical use. Pharmacol Rev, 58(3), 488-520. https://doi.org/10.1124/pr.58.3.5

Burgin, A. B., Magnusson, O. T., Singh, J., et al. (2010). Design of phosphodiesterase 4D (PDE4D) allosteric modulators for enhancing cognition with improved safety. Nat Biotechnol, 28, 63-70. https://doi.org/10.1038/nbt.1598

Chen, Y., Li, C. X., Zhang, M., Chen, Y. J., Tian, Y. Y., \& Wang, Y. S. (2020). Heterologous expression, purification and enzymatic analysis of Candida albicans evclic nucleotide phosphodiesterase 2. Food Science. https://doi.org/10.7506/spkx1002-6630-20191012-092 
Claffey, M. M., Helal, C. J., Verhoest, P. R., et al. Application of structure-based drug design and parallel chemistry to identify selective, brain penetrant, in vivo active phosphodiesterase 9A inhibitors. J Med Chem, 55(21), 9055-9068. https://doi.org/10.1021/jm3009635

Conti, M., \& Beavo, J. (2007). Biochemistry and physiology of Cyclic nucleotide phosphodiesterases: essential Components in cyclic nucleotide signaling. Annu. Rev. Biochem., 76(3), 481-511. https://doi.org/10.1146/annurev.biochem.76.060305.150444

Conti, M., Richter, W., Mehats, C., et al. (2003). Cyclic AMP-specific PDE4 phosphodiester as critical components of cyclic AMP signaling. J. Biol. Chem., 278(8), 5493-5496. https://doi.org/10.1074/jbc.R200029200

Esposito, K., Reierson, G. W., Luo, H. R., et al. (2009). PhosPhodiesterase genes and antidepressant treatment Response: a review. Ann. Med., 41(11), 177-185. https://doi.org/10.1080/07853890802441169

Hebb, A. L. O., \& Robertson, H. A. (2007). Role of phosphodiesterases in neurological and $\begin{array}{llll}\text { psychiatric disease. Curr. Opin. } & \text { Pharmacol., } & \text { 86-92. }\end{array}$ https://doi.org/10.1016/j.coph.2006.08.014

Houslay, M. D., Schafer, P., \& Zhang, K. Y. (2005). Keynotere-View:phosphodiesterase-4asatherapeutictarget. Drug Discov Today, 10(22), 1503-1519. https://doi.org/10.1016/S1359-6446(05)03622-6

Hutson, P. H., Finger, E. N., Magliaro, B. C., Smith, S. M., Converso, A., Sanderson, P. E, ... Parmentier-Batteur, S. (2011). The selective phosphodiesterase 9 (PDE9) inhibitor PF-04447943 (6-[(3S, 4S) -4-methyl-1- (pyrimidin-2-ylmethyl) pyrrolidin-3-yl]-1(tetrahydro-2H-py ran-4-yl) -1,5-dihydro- 4H-pyrazolo [3,4-d] pyrimidin-4-one) enhances synaptic plasticity and cognitive function in rodents. Neuropharmacology, 61(4), 665-676. https://doi.org/10.1016/j.neuropharm.2011.05.009

Jian, Z., et al. (2013). Structural Basis for Inhibitor Selectivity of Phosphodiesterase 2. Fudan University. https://doi.org/10.7666/d.Y2866400

Kennedy, S. H. (2013). A review of antidepressant therapy in primary care: current practices and future directions. Prim Care Companion CNS Disord, 15(2). pii: PCC.12r01420. https://doi.org/10.4088/PCC.12r01420

Lakics, V., Karran, E. H., \& Boess, F. G. (2010). Quantitative comparison of phosphodiesterase mRNA distribution in human brain and peripheral tissues. Neuropharmacology, 59, 367-74. https://doi.org/10.1016/j.neuropharm.2010.05.004

Mann, J. J. (2003). Neurobiology of suicidal behavior [J]. Nat Rev Neurosci, 4(10), 819-828. https://doi.org/10.1038/nrn1220

Mathew, S. J., Manji, H. K., \& Charney, D. S. (2008). Novel drugs and therapeutic targets for severe mood disorders. Neuropsychopharmacology, 33, 2080-2092. https://doi.org/10.1038/sj.npp.1301652 


\section{Macrothink}

Journal of Biology and Life Science ISSN 2157-6076 2020, Vol. 11, No. 2

Meng, F., Hou, J., Shao, Y. X., et al. (2012). Structure-based discovery of highly selective phosphodiesterase-9A inhibitors and implications for inhibitor design. J. Med. Chem., 55(19), 8549-8558. https://doi.org/10.1021/jm301189c

O'Donnell, J., \& Zhang, H. (2004). Antidepressant effects of inhibitors of cAMP phosphodiesterase (PDE4). Trends Pharmacol Sci, 25, 158-163. https://doi.org/10.1016/j.tips.2004.01.003

Shao, Y. X., Huang, M., Cui, W., et al. Discovery of a phosphodiesterase 9A inhibitor as a potential hypoglycemic agent. J Med Chem, 57(24), 10304-10313. https://doi.org/10.1021/jm500836h

Song, Y., Huang, Y., Liu, D., et a1. (2008). Depression in college: depressive symptoms and personality factors in Beijing and Hong Kong college freshmen. Compr. Psychiatry., 49(5), 496-502. https://doi.org/10.1016/j.comppsych.2008.02.005

Teng, F. Y., \& Tang, B. L. (2006). Axonal regeneration in adult CNS neurons-signaling molecules and pathways. J. Neuro. Chem., 96(6), 1501-1508. https://doi.org/10.1111/j.1471-4159.2006.03663.x

Zeller, E., Stief, H. J., Pflug, B., et al. (1984). Results of a phase II study of theantidepressant effect of rolipram. Pharmacopsychiatry, 17, 188-90. https://doi.org/10.1055/s-2007-1017435

Zhang, C., Lueptow, L. M., Zhang, H. T., O'Donnell, J. M., \& Xu, Y. (2017). The Role of Phosphodiesterase-2 in Psychiatric and Neurodegenerative Disorders. Advances in Neurobiology, 17, 307-347. https://doi.org/10.1007/978-3-319-58811-7_12

Zhang, H. T., Huang, Y., Jin, S. L., et al. (2002). Antidepressant-like profile and reduced sensitivity to rolipram in mice deficient in the PDE4D phosphodiesterase enzyme. Neuropsychopharmacology, 27, 587-595. https://doi.org/10.1016/S0893-133X(02)00344-5

\section{Copyright Disclaimer}

Copyright for this article is retained by the author(s), with first publication rights granted to the journal.

This is an open-access article distributed under the terms and conditions of the Creative Commons Attribution license (http://creativecommons.org/licenses/by/4.0/). 